\title{
EXPERIENTIAL LEARNING: AN ANALYSIS OF IMPACT ON ACADEMIC ACHIEVEMENT AMONG STUDENTS OF GRADE 12
}

\author{
Prashant Thote ${ }^{*} \bowtie$, Gowri. S 2 \\ *1, 2 Gyanodaya Vidya Mandir, India
}

DOI: https://doi.org/10.29121/granthaalayah.v8.i9.2020.1337

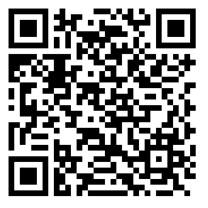

Article Type: Research Article

Article Citation: Prashant Thote, and Gowri. S. (2020).

EXPERIENTIAL LEARNING: AN

ANALYSIS OF IMPACT ON

ACADEMIC ACHIEVEMENT AMONG

STUDENTS OF GRADE 12.

International Journal of Research -

GRANTHAALAYAH, 8(9), 188-199.

https://doi.org/10.29121/granthaa

layah.v8.i9.2020.1337

Received Date: 28 August 2020

Accepted Date: 30 September 2020

Keywords:

Models

Chemistry

Visualization

Unit Cell and Solid State

\section{ABSTRACT}

The molecular model as a learning tool in class-room instructions is significant due to its positive effect on the learning and teaching process. Many students struggle to learn Chemistry and do not succeed. Chemistry is the central part of all Science subjects. To make Chemistry learning easy and joyful appropriate method of class-room instructions are important. The Chemistry of solid states and composite materials is the part of the curriculum at All India Senior Secondary School Curriculum. Students face problems in solid state Chemistry due to its abstract concepts. To address the issue, handmade models and paper-based models are made as evidence-based learning. In this present paper attempt is made to investigate the impact of handmade paper model of unit cell and crystal lattices of solid-state Chemistry on academic achievement. The study is delimited to the students of only one school in rural area. Totally 50 students participate in the study. Sample is distributed into two groups: study group and the control group, by connecting them on the basis of the previous knowledge which is determined through pre-test. The students of the study group are taught solid states Chemistry through handmade paper models of unit cells and crystal lattices and the students of the control group are taught by using traditional chalk and board method. Data is collected by using Test (Pre and Post). Mean standard deviation and mean differences are used as a statistical tool to analyze the data. Substantial difference between the study group and the control group of mean score on test (pre and post and retention) are tested at 0.05 level. The handmade paper model of unit cell and crystal lattices of solid states Chemistry has significant positive impact on the academic achievement in solid state Chemistry. Based on the findings of the present study, some recommendations are made for using paper model as teaching aid for evidence-based learning in Chemistry and other core subjects to move up the students' academic performance level.

\section{INTRODUCTION}

"Your attitude, not your aptitude will determine your altitude" - zig Ziglar

(C) 2020 The Author(s). This is an open access article distributed under the terms of the Creative Commons Attribution License, which permits unrestricted use, distribution, and reproduction in any medium, provided the original author and source are credited. 
$21^{\text {st }}$ century belongs to Science and technology and economy is knowledge based. Science education has concern for policy makers. Emphasis is to develop a scientific attitude among students. The class-room instructions must be designated to stress scientific attitude. Many students struggle to learn Chemistry and not able to understand the basic concept of Chemistry. Inadequate and inappropriate understanding of fundamental concepts among the students triggers the challenges of conceptual understanding of advance concept that builds upon the fundamental concepts. Chemistry is regarded as not easy, interesting, joyful experience subject due to its abstract nature of concepts, traditional teaching methodology and absence of teaching aids during classroom instructions and difficulty of language of Chemistry. All these factors lead to the development of poor conceptual understanding, misunderstanding, learning difficulties and development of alternative concepts. Learning difficulties are important for both teaching and learning.

Chemistry is an important branch of Science which enables the learner to comprehend what happens around them. Topics in Chemistry are related to properties and structures of matter. Chemistry curriculum is commonly incorporated with many abstract concepts and is central to the further learning in Chemistry and other related branches of Science. These abstract concepts are important because further concept and theories are not be easy to understand if these under-pins concepts are not adequately grasped by the learners. The abstract nature of the Chemistry along with other content makes learning difficult; for example numerical. Chemistry class requires high order thinking skills too.

The essential characteristic of Chemistry is content interplay between microscopic and macroscopic level of thoughts. It represents the significant challenges to novices. Chemistry by nature is rich in conceptual contents. It essentially requires deep understanding and brings together the conceptual understanding in a meaningful way. Learners exhibit the evidence of learning and understanding through assessment and evaluation may be the evidence of misconception, alternative concept, rote learning and lack of fundamental conceptual understanding. What taught is not always what is learnt.

As Chemistry teacher am using handmade waste paper model to represent structures in Chemistry. I have also used Styrofoam balls cut into halves, quarters and eights and are glued to photo cube. Such handmade models are vivid and are highly useful for small size group students. The templates and clear plastic spheres are commonly used models in the classroom instructions of Chemistry but cannot be sliced to depict the contents of unit cell to classroom instructions as individual based learning and to familiarize the learners with unit cell and crystal lattices. It is not advantageous to use readymade models and teachers made models. Student's handmade models are highly effective and acts as a simple teaching tool for evidence-based learning.

In the present study handmade waste paper model on unit cell and crystal lattices are made. Students are asked to construct the unit cell and crystal lattice as a homework assignment. Students use creative and innovative approach to design the unit cell and the crystal lattices. Students use two types of design to make a unit cell- body centered cubic unit cell with certain shortcomings. The template gives one of two halves of a body-centered cubic unit cell -body centered. At one corner, two of these are trapped. The handmade waste paper model effectively represents the atom at the center on the opening of the unit cell but has deficiency -the center atom is not visible on faces but can be observed through dissected view.

The use of making handmade model from waste paper is an effective tool for individual learning as evidencebased learning. The handmade models are used to make unit cell and crystal lattice also. Students also make a simple hexagonal unit cell but are not used to illustrate the efficiency of hexagonal closed packing as it is not in the position to show the image of atom inside the unit cell. This model is used to explicit the packing of hexagonal crystal lattice. Hexagonal unit cell contains six fold axis but only three fold and two fold axis are easy to identify from the model presented by the students. Learners may compare the number of repeating unit (unit cell) that are essential to make the full atom by comparing and contrasting the cubic crystal system (six and eight unit cell).

The handmade model of Sodium Chloride crystal lattice is constructed and it exhibits the efficiency of packing pattern but the deficiency is that the atom at the center of the body $(1 / 2,1 / 2,1 / 2)$ is not visible. Hence students may use the model of Sodium Crystal lattice to count the correct number of repeating units per cell (cell). Waste cardboard paper of size 9.5 inches and 12.5 inches and cube size of seven inches are designed by a student. Learner's cut out the figures and folds the paper along each line. Tabs are glued inside the cube to construct the unit cell. This experiential activity is interesting, motivating and joyful for the learners.

The unit cell (A and B) is designed to make sure that the learners will be able to understand the structure of cubic unit cell in context to crystalline lattice. Before introducing the unit, the handouts that are prepared by the teacher on the template of making the unit cell is distributed to the students of the study group. The templates are 
designed in such a fashion that the students are able to cut and glue to form the cube and demonstrate the assembled model. The assembling of unit cell - an experiential learning activity; is simple, easy, interesting, fascinating and joyful to make a handmade model from waste paper. The microscopic diagram of fourteen types of unit cells and seven types crystal lattices are shown and discussed based on their structure and arrangement by comparing and contrasting the solid. Students prepare different sorts of unit cell and exhibit the model to fabricate the model of crystalline lattice.
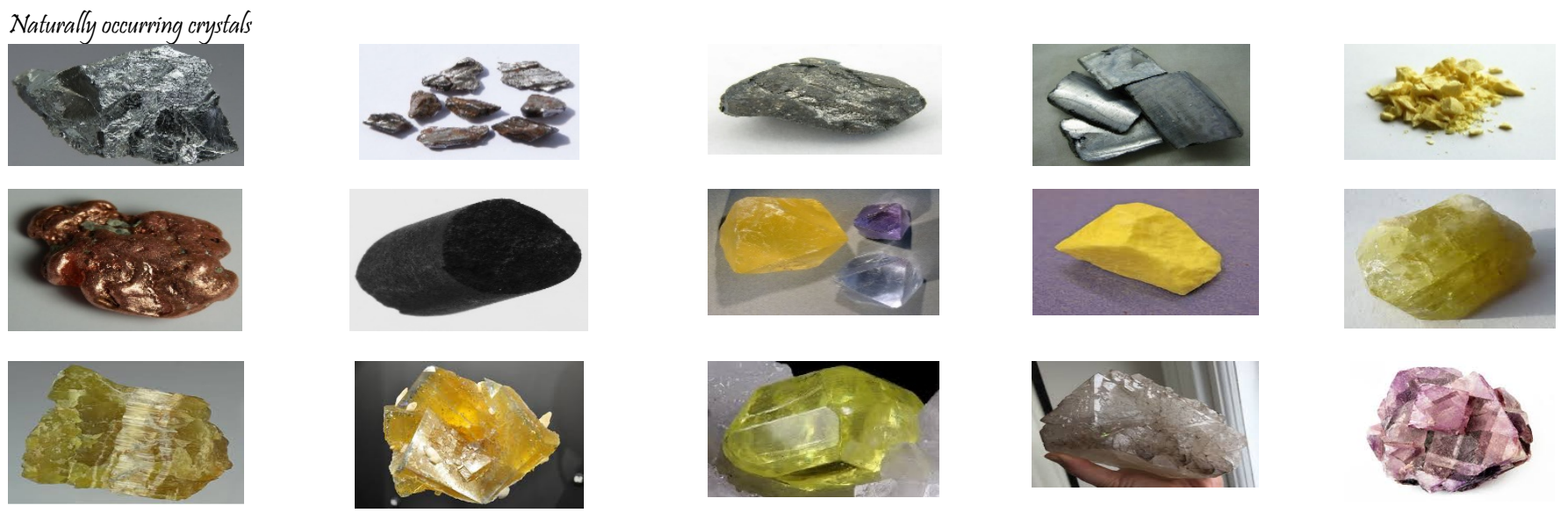

Paper Based Xodel
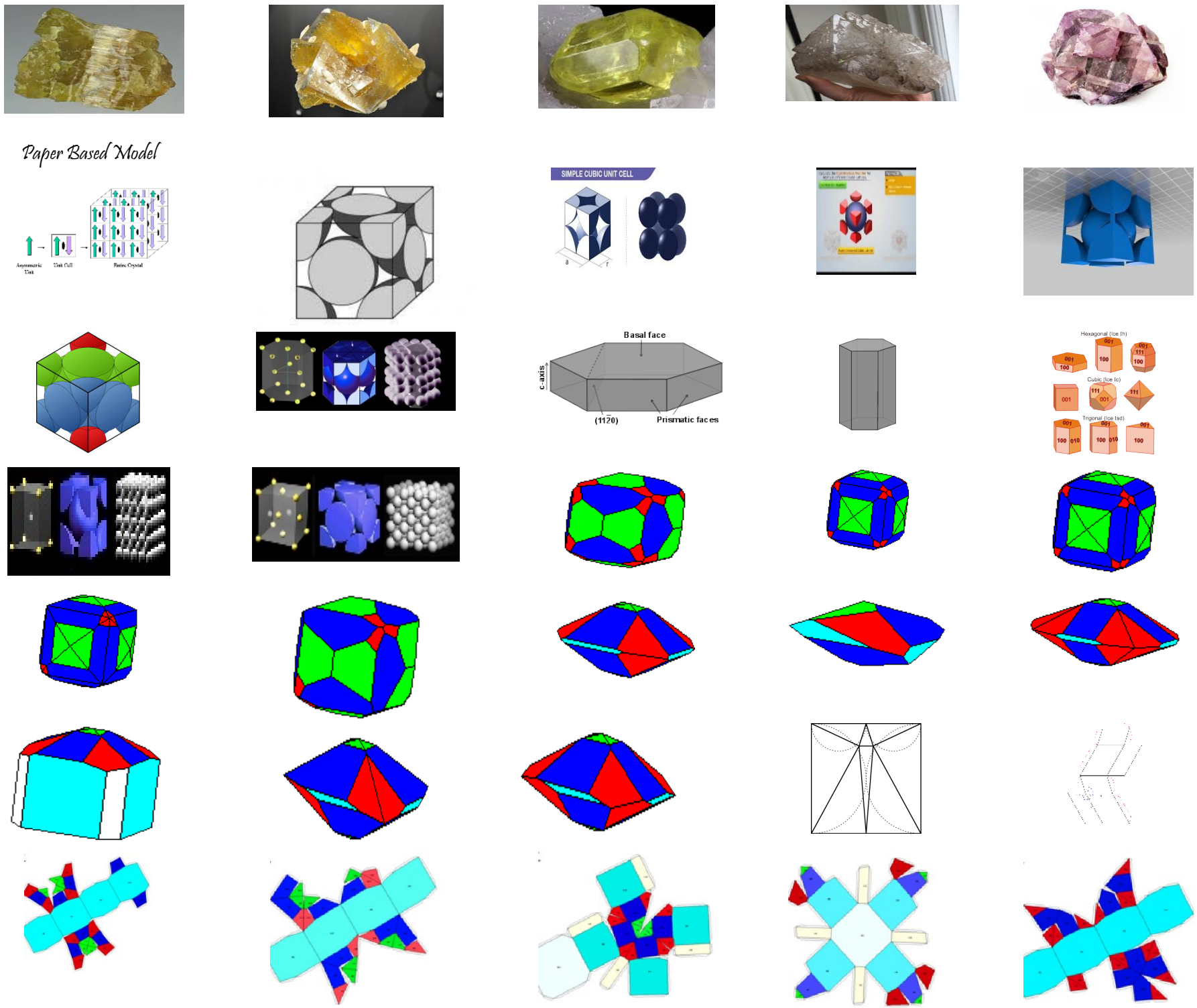

Project based :Hand -made model of waste paper 

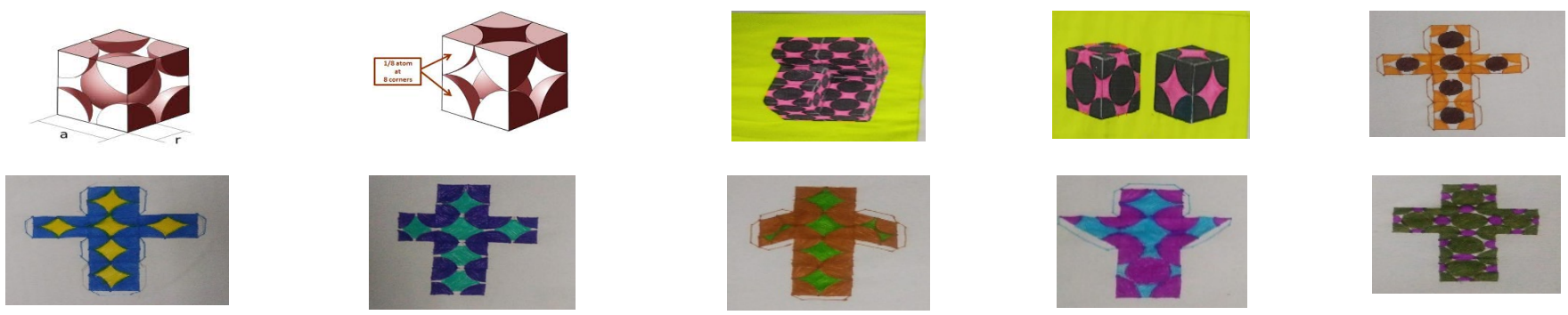

The handmade model from waste paper is highly effective and exhibits how eighth quarter and halves make complete unit of crystalline lattice solid. Students may examine the voids in structures of unit cell dictates the shapes of cubic, octahedral and tetrahedral. Students of the study group are taught by using handmade models prepared from waste material and students of the control group are taught by using traditional chalk and talk method.

\subsection{STATEMENT OF THE PROBLEM}

The present paper is designed to explore the effectiveness of student's handmade model in Chemistry on academic performance of students'. "An Analysis of Impact of Evidence Based Learning on Academic Achievement of Students" is the title of the problem of the present study.

\subsection{OBJECTIVES}

The following objectives are framed to guide the study:

- To investigate the efficiency of the models made from waste paper by the students on their academic performance in subject Chemistry among the students of Grade 12.

- To suggest recommendations for the enhancement of the learner's academic performance in subject Chemistry among the students of Grade 12.

\subsection{HYPOTHESIS}

The following null hypothesis are designed for the achieving the above mentioned objectives

$\mathrm{H}_{0} 1$ : There is no noteworthy change on the achievement of the learners of both study group (experimental and control) on pre-test.

$\mathrm{H}_{0} 2$ : There is no noteworthy change on the achievement of the learners of both study group (experimental and control) on post-test.

$\mathrm{H}_{0} 3$ : There is no noteworthy change on the achievement of the learners of both study group (experimental and control) on retention test.

\section{METHODS}

\subsection{POPULATION}

All Higher Secondary School students studying Chemistry at the Senior Secondary School level constitute the population.

\subsection{SAMPLE AND TECHNIQUES}

Fifty students of Grade 12 of Higher Secondary School in rural area are selected. Purposive sampling technique is used to draw the sample. Students are divided into two groups (experimental and control). Each group consists of 25 students. 


\subsection{DELIMITATIONS OF THE STUDY}

- The present study is delimited only to the students of one private rural school.

- The study further delimits to the students of Grade 12.

- The study is also delimited to only one unit of Chemistry- solid state.

- The study is also delimited to the co-educational school only.

\subsection{RESEARCH DESIGN}

Experimental research design is employed. The pre-test -post-test equivalent group design is applied. Students are randomly adjusted to both groups and the following symbolic representations of study devices are used:

$$
\begin{array}{lll}
R E=01 & T & 02 \\
R C=03 & T & 04
\end{array}
$$
Where
$\mathrm{R} \longrightarrow$ Randomly selected
$\mathrm{E} \longrightarrow$ Experimental group
$\mathrm{C} \longrightarrow$ Control group
$\mathrm{O} \longrightarrow$ Observation
$\mathrm{T} \longrightarrow$ Experimental treatment

\subsection{TOOL}

Experimental research design is employed. Test-pre and test -post method is used to collect the data. Question paper is made on the unit "solid state" in Chemistry based on the source of revised Bloom's Taxonomy and distributed to both the groups before treatment.

Another question paper is made and distributed to the learners of both groups after the treatment. The two question papers which are applied to the present research are the tools for collecting data.
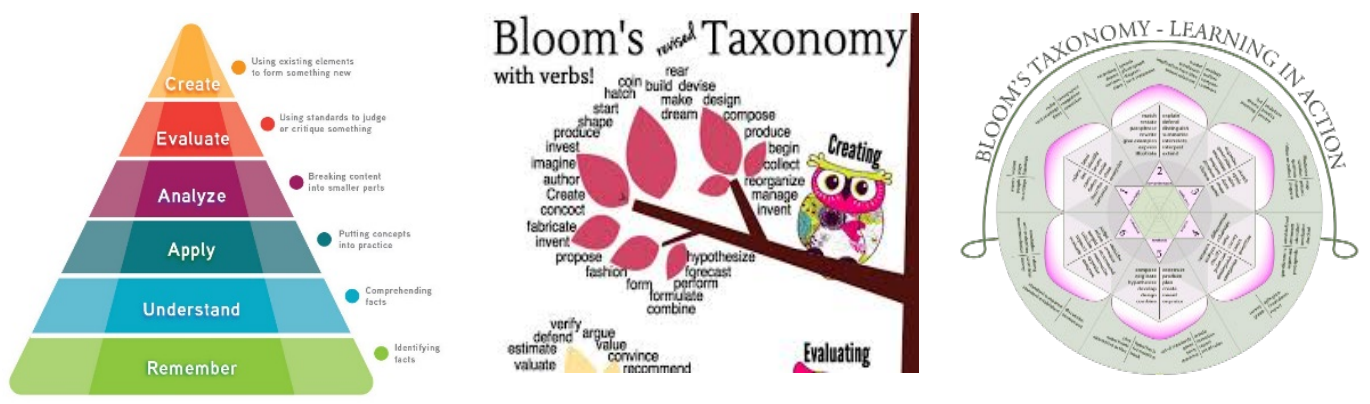

Figure 1: Revised Blooms Taxonomy

\begin{tabular}{|c|c|c|c|c|c|c|c|c|}
\hline Sl.No & Typology of Questions & $\begin{array}{c}\text { Very } \\
\text { Short } \\
\text { Answer } \\
\text { (VSA) } \\
\text { (1 mark) }\end{array}$ & $\begin{array}{c}\text { Short } \\
\text { Answer } \\
-\mathrm{I} \\
(\mathrm{SA}-\mathrm{I}) \\
(2 \\
\text { marks) }\end{array}$ & $\begin{array}{c}\text { Short } \\
\text { Answer } \\
- \text { II } \\
\text { (SA-II) } \\
\text { (3 } \\
\text { marks) }\end{array}$ & $\begin{array}{c}\text { Value } \\
\text { Based } \\
\text { Question } \\
\text { (VBQ) } \\
\text { (4 marks) }\end{array}$ & $\begin{array}{c}\text { Long } \\
\text { Answer } \\
\text { (LA) } \\
(5 \text { marks) }\end{array}$ & $\begin{array}{l}\text { Total } \\
\text { Marks }\end{array}$ & $\begin{array}{c}\% \\
\text { Weightage }\end{array}$ \\
\hline 1 & Remembering: & 2 & 1 & 1 & - & - & 7 & $10 \%$ \\
\hline
\end{tabular}

Table 1: Blue print of the Question Paper Blue Print of the Question Paper 
Experiential Learning: An Analysis of Impact on Academic Achievement Among Students of Grade 12

\begin{tabular}{|c|c|c|c|c|c|c|c|c|}
\hline & $\begin{array}{l}\text { Knowledge based simple } \\
\text { recall questions, to know } \\
\text { specific facts, terms, } \\
\text { concepts, principles or } \\
\text { theories, identify, define or } \\
\text { recite information }\end{array}$ & & & & & & & \\
\hline 2 & $\begin{array}{l}\text { Understanding/ } \\
\text { Comprehension: } \\
\text { To be familiar with } \\
\text { meaning and to understand } \\
\text { conceptually, interpret, } \\
\text { compare, contrast, explain, } \\
\text { paraphrase information }\end{array}$ & - & 2 & 4 & - & 1 & 21 & $30 \%$ \\
\hline 3 & $\begin{array}{c}\text { Application: } \\
\text { Use abstract information in } \\
\text { concrete situation, to apply } \\
\text { knowledge to new } \\
\text { situations, use given } \\
\text { content to interpret a } \\
\text { situation, provide an } \\
\text { example, or solve a } \\
\text { problem) }\end{array}$ & - & 2 & 4 & - & 1 & 21 & $30 \%$ \\
\hline 4 & $\begin{array}{l}\text { High Order Thinking Skills: } \\
\text { Analysis \& Synthesis- } \\
\text { classify, compare, contrast } \\
\text { or differentiate between } \\
\text { different pieces of } \\
\text { information, organize } \\
\text { and/or integrate unique } \\
\text { pieces of information from } \\
\text { a variety of sources }\end{array}$ & 2 & - & 1 & - & 1 & 10 & $14 \%$ \\
\hline 5 & $\begin{array}{c}\text { Evaluation: } \\
\text { Appraise, judge and/or } \\
\text { justify the value or worth of } \\
\text { a decision or outcome, or to } \\
\text { predict outcomes based on } \\
\text { values }\end{array}$ & 1 & - & 2 & 1 & - & 11 & $16 \%$ \\
\hline
\end{tabular}

Table 2: Question Wise Break Up

\begin{tabular}{|c|c|c|c|}
\hline Type of Question(s) & Mark(s) per Question & Total No. of Questions & Total Marks \\
\hline VSA & 1 & 5 & 05 \\
\hline SA-I & 2 & 5 & 10 \\
\hline SA-II & 3 & 12 & 36 \\
\hline VBQ & 4 & 1 & 4 \\
\hline LA & 5 & 3 & 15 \\
\hline Total & & $\mathbf{2 6}$ & $\mathbf{7 0}$ \\
\hline
\end{tabular}

1) Internal Choice: There is no overall choice in the paper. However, there is an internal choice in one question of 2 marks weightage, one question of 3 marks weightage and all the three questions of 5 marks weightage.

2) The above template is only a sample. Suitable internal variations may be made for generating similar templates keeping the overall weightage to different form of questions and typology of questions same. 
Prashant Thote, and Gowri. S

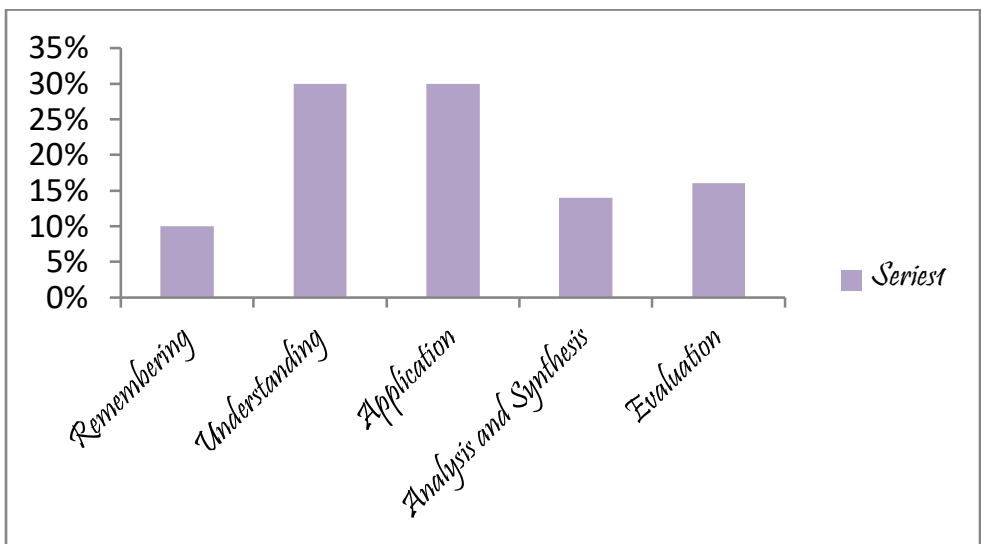

Figure 2: Question paper based on revised Bloom's Taxonomy

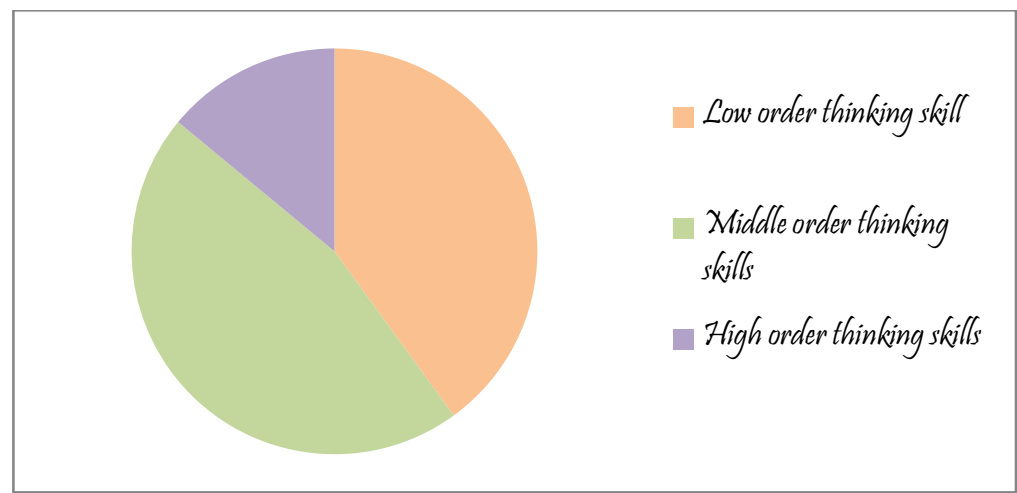

Figure 3: Question based on order of thinking

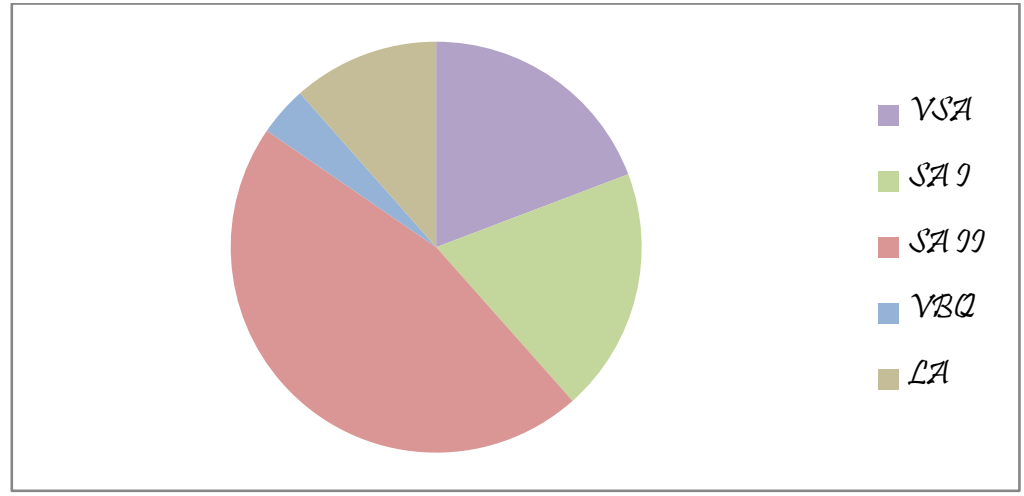

Figure 4: Question paper Question wise break up

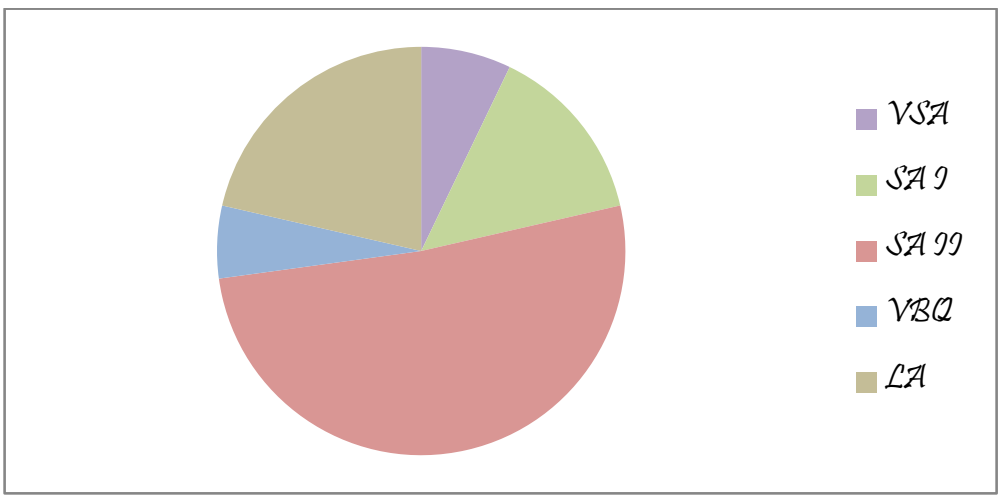

Figure 5: Question paper mark wise break up 


\subsection{DATA COLLECTION}

To collect the data pre-test -post-test and retention test was applied to both study groups (Experimental and Control). Question paper were developed coved unit of solid state of chemistry of Grade 12. Raw data collected by conducting the unit -test (pre-test -post-test and retention test).

\subsection{ANALYSIS OF DATA}

The test is conducted before the treatment and after the treatment and is presented in the tabular form. Mean, standard deviation, mean difference is calculated as statistical tool. Significance difference between the groups of mean score for both groups (experimental and control) on variables of pre-test-post-test and retention test is checked at 0.05 level by applying three-unit tests.

\section{RESULT AND DISCUSSIONS}

Table 3: pre-test score

\begin{tabular}{|c|c|c|c|c|c|c|}
\hline Groups & $\mathrm{N}$ & Mean & SD & SE & t-value & p-value \\
\hline Experimental & 25 & 46.32 & 2.41 & 0.79 & 0.049 & 9.61 \\
\hline Control & 25 & 43.28 & 2.51 & & & \\
\hline
\end{tabular}

Non-significant $(\mathrm{p}>0.05) \mathrm{df}=38 \quad \mathrm{t}$ (table value) at $0.05=2.02$

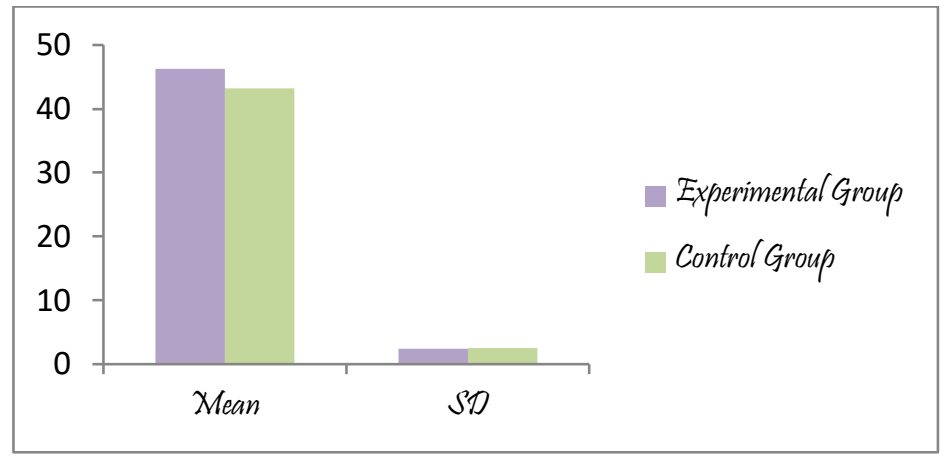

Figure 5: Pre-test score

Table 4: Post-test Score

\begin{tabular}{|c|c|c|c|c|c|c|}
\hline Groups & $\mathrm{N}$ & Mean & SD & SE & t-value & p-value \\
\hline Experimental & 25 & 91.23 & 1.92 & 0.85 & 27.94 & 0.00 \\
\hline Control & 25 & 67.28 & 3.79 & & & \\
\hline
\end{tabular}

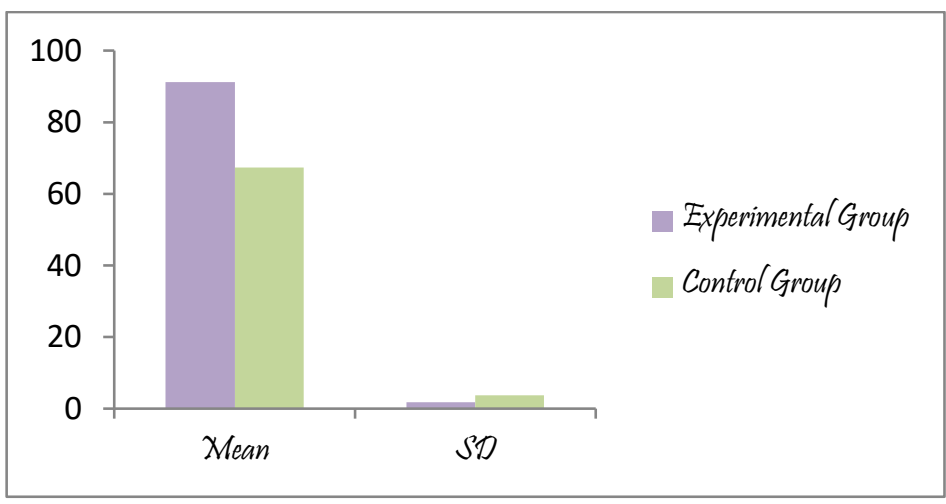

Figure 6: Post-test score 
Prashant Thote, and Gowri. S

Table 5: Retention Score

\begin{tabular}{|c|c|c|c|c|c|c|}
\hline Groups & $\mathrm{N}$ & Mean & SD & SE & t-value & p-value \\
\hline Experimental & 25 & 88.72 & 2.51 & 0.063 & 83.22 & 0.00 \\
\hline Control & 25 & 64.72 & 1.92 & & & \\
\hline
\end{tabular}

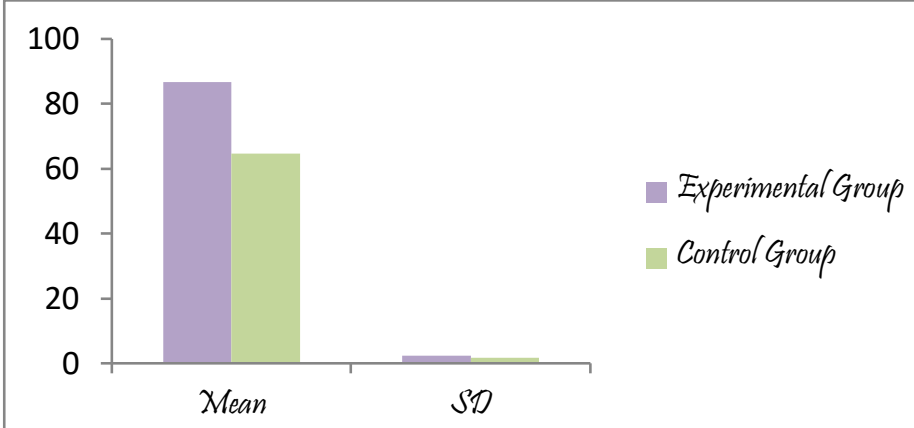

Figure 7: Retention test score

The intention of the study is to probe the effect of hand made models on student's academic performance of Senior Secondary School in Chemistry. The student of the study group (Experimental) is taught the unit solid state by using studnets' hand made model and control group is taught by using traditional chalk and talk method. The conceptual objectives of the units are:

\subsection{SOLID STATE}

- Solids: their classification based on different binding forces such as: iconic, covalent molecular; amorphous and crystalline solids (difference), metals.

- Types of unit cell in two dimensional and three dimensional lattices, number of atoms per unit cell (all types).

- Calculation of density of unit cell, packing in solids, packing efficiency,

- voids, point defects, electrical and magnetic properties.

- Band theory of metals, conductors, semiconductors ( $n$ and p type) and insulators.

1) Crystalline and amorphous solids

2) Definition of crystal lattice, unit cell; types of unit cell(scc, fcc, bcc); calculation of the number of atoms per unit cell; relationship between radius, edge, length and nearest neighbor distance. Calculation of density of unit cell, formula of the compound-numerical based on it; packing in 3-D, packing fraction in scc, fcc, bcc with derivation; voids-types, location, formation (derivation of radius of voids).

3) Characteristics of crystalline solids- ionic $(\mathrm{NaCl})$, metallic $(\mathrm{Cu})$, atomic (diamond and graphite).

4) Point defects: Stoichiometric, nonstoichiometric and impurity defects (F-centres).

5) Electrical properties: conductors, semiconductors ( $\mathrm{n} \& \mathrm{p}$ types) and insulators (Band Theory), piezoelectricity and pyro electricity.

6) Magnetic properties: diamagnetic, paramagnetic, ferromagnetic, ferromagnetic and antiferromagnetic.

\subsection{CONCEPTUAL OBJECTIVES}

- General characteristics of solid states

- Crystaline and amarphous solids

- Classification of crytaline solids

- Crystallography

- Space lattics/crystal lattics/unit cells

- Types of unit cells

- Calculation of the number of points (particles o atoms) in a unit cell 
Experiential Learning: An Analysis of Impact on Academic Achievement Among Students of Grade 12

- $\quad$ Closed paket structures

- Tetrahedral/octahedral voids/interstitial sites

- Formation of compounds and number voids filled

- Stability of ionic crystalline solids in terms of Radii of cations and anions.

- Packing efficiency

- Structures of simple iconic crystals

- Calculations involving unit cell dimensions

- Imperfections or defects in crystalline solids

- Types of point defects

- Nature of bonding in metallic solids

- Properties of solids

- Electrical properties of solids

- Magnetic properties of solids

\subsection{TARGET- BOARD EXAMINATIONS}

- $\quad$ N.C.E.R.T. In - Text Questions

- N.C.E.R.T Exercise

- N.C.E.R.T Exemplar Problems with Solution

- Short Answer Type Questions

- Long Answer Type Questions

- Additional Important Questions

- Questions from Board Examinations

- H.O.T.S. Questions

- Value Based Questions

- Assignment

- Solution to Problems for Practice

\subsection{TARGET- COMPETITIVE EXAMINATIONS}

- Useful Information for Competitive Examinations

- Multiple Choice Question Bank (MCQB)

- $\quad$ AIPMT \& Other Medical Entrance Examinations

- JEE (Main) \& Other Engineering Entrance Examinations

- JEE (Joint Entrance Examination) Advanced

- Brain Storming MCQs

The solid state unit is covered in 25 periods with 45 minutes duration and treatment lasts for two weeks. After two weeks, Chemistry teacher conducts the post-test with the slight changes in the sequence of the questions and a retention test to the test for both groups (experimental and control group). Data is collected and compared. The complete statistical process is as under.

$\mathrm{H}_{0} 1$ : There is no significant change on the achievement of the learners of both study group (experimental and control) on pre-test.

Result in Table -3 shows that the calculated t-value is found to be 0.009 which is statistically non-significant, as it is less than critical value $\mathrm{t}=2.02$ at 0.05 level.

Hence the null hypothesis "There is no significant change on the achievement of the learners of both study group (experimental and control) on pre-test" is rejected and accepted. Result unanimously shows that learners of both groups show equal performance on pre-test.

$\mathrm{H}_{0} 2$ : There is no noteworthy change on the achievement of the learners of both study group (experimental and control) on post-test. 
Result in Table-4 depicts that the computed value of $t$ is found to be 27.91 and it is statistically significant and is more than the critical table value of $t$ at 0.05 level. Hence null hypothesis "there is no noteworthy change on the achievement of the learners of both study group (experimental and control) on post-test" is rejected and is not accepted. It clearly indicates that the learners of experimental group show significantly excellent performance as compared to the learners of control group on post-test.

$\mathrm{H}_{0} 3$ : There is no noteworthy change on the achievement of the learners of both study group (experimental and control) on retention-test.

Result in Table -5 indicates that the computed $t$ value is found to be 33.19 and statistically significant and is greater than that of the table value of $t$ at 0.05 level. Hence the null hypothesis "There is no noteworthy change on the achievement of the learners of both study group (experimental and control) on retention-test" is not accepted and rejected. It explicitly depicts that the learners of experimental group shows excellent achievement as compared to the learners of the control group in retention test.

\section{CONCLUSION}

Statistical data analyses of research arrive at the following conclusions:

- There is a significantly positive impact of student's handmade model as outcome-based learning on the academic performance in subject Chemistry at Senior Secondary School level. The outcome-based learning as student's handmade models are effective and efficient in enhancing the achievement level and conceptual understanding in chemistry. It is also useful in identifying the difficult concept in Chemistry for students.

- The students of experimental group show surprisingly better improvement than the learners of control group. The outcome-based learning in the form of handmade model of unit cell and crystal lattices in subject Chemistry is highly effective tool by active participation of learners which makes the learners a joyful learning experience and students learns at their own speed and space. Hence it is an individual base learning approach. It acts as a motivational catalyst for the conceptual retention of knowledge, skills and competence.

\subsection{CONCLUDING REMARKS}

In nutshell it is concluded that outcome-based learning approach by making handmade model of unit cell and crystal lattice in solid state Chemistry has positive significant impact on academic achievements of learners.

\subsection{RECOMMENDATIONS}

Keeping the view of above conclusion the researcher the following recommendations are made:

- The outcome-based learning through making handmade model is very effective and it enhances the performance level of the learners in the subject of Chemistry and hence it may be replicated.

- Chemistry is considered as a difficult subject due to its abstract concept, hence outcome-based learning is effective teaching pedagogy.

- Handmade model plays a significant role and it enhances the academic performance in Chemistry as experiential learning activity. Hence it can be used as a teaching aid in classroom instructions.

- Models are powerful teaching tool but must be used with caution in Chemistry. When using the model in classroom instructions keep the following instructions in mind:

- Test your model carefully makes sure that it gives result that you intended in classroom instructions.

- Use model in teaching -learning to enhance the constructs of mental model of concept fully reaches.

\section{SOURCES OF FUNDING}

This research received no specific grant from any funding agency in the public, commercial, or not-for-profit sectors.

International Journal of Research -GRANTHAALAYAH 
Experiential Learning: An Analysis of Impact on Academic Achievement Among Students of Grade 12

\section{CONFLICT OF INTEREST}

The author have declared that no competing interests exist.

\section{ACKNOWLEDGMENT}

None.

\section{REFERENCES}

[1] Ajunwa, C. (2000), Acquisition of physics process skills by secondary school students, Department of Education, University of Nigeria, Nsukka.

[2] Amanso, E. O.I., \& Bassey, B.A. (2017), Assessment of Selected Science Process Skills Acquisition among Senior Secondary Schools Students in Calabar Education Zone of Cross River State, Nigeria. International Journal of Scientific Research in Education, 10(1), 119-126

[3] Ayas, A., Cepni, S., Akdeniz, A., Ozmen, H., Yigit, N., \& Ayvaci, H.S. (2007), Science and Technology Teaching from Theory to Application (6th Ed.). Ankara; Pegem A Publishing.

[4] Terniz, B.K., Assessing Science Process Skills in Physics Teaching (Ph.D. Thesis). Gazi University, Institute of Education Science, Ankara, Turkey.

[5] Prashant Thote, Experiential Learning: Inclusive Art Education for Joyful Learning, Review of Research, Vol 8, Issue- 09, June 2019.

[6] Prashant Thote, Experiential Learning: Model for Teaching Science at Grade Nine, Research Magma, Vol-3, Issue -06, August - 2019. 